\title{
LANDSCAPE ECOLOGICAL ANALYSIS OF THE MODERN DELTA OF THE URAL (ZHAYIK) RIVER
}

\author{
Yerlan S. KABIYEV* \\ L.N. Gumilyov Eurasian National University, Department of Physical and Economical \\ Geography, 2 Mirzoyan st., 010008, Astana, Kazakhstan, e-mail: yerlanustaz@gmail.com

\section{Zharas G. BERDENOV} \\ L.N. Gumilyov Eurasian National University, Department of Physical and Economical \\ Geography, 2 Mirzoyan st., 010008, Astana, Kazakhstan, e-mail: berdenov.87@mail.ru
}

\section{Kulchihan M. DZHANALEEVA}

L.N. Gumilyov Eurasian National University, Department of Physical and Economical Geography, 2 Mirzoyan st., 010008, Astana, Kazakhstan, e-mail: erlan_88_kz@mail.ru

\section{Emin ATASOY}

Uludag University, Department of Elementary Education, Faculty of Education, Gorukle Campus, Bursa, Turkey, e-mail: geograf1967@gmail.com

\section{Jan A. WENDT}

Gdańsk University, Faculty of Oceanography and Geography, Institute of Geography, Bażyńskiego Str. 4, 80-309 Gdańsk, Poland, e-mail: jan.wendt@ug.edu.pl

Citation: Kabiyev, Y. S., Berdenov, Z. G., Dzhanaleeva, K. M., Atasoy, E., \& Wendt, J. A. (2018). LANDSCAPE ECOLOGICAL ANALYSIS OF THE MODERN DELTA OF THE URAL (ZHAYIK) RIVER. GeoJournal of Tourism and Geosites, 23(3), 644-655. https://doi.org/10.30892/gtg.23302-316

\begin{abstract}
Varied tourist values of places increase the possibility of practicing various forms of tourism. This study presents a landscape and ecological analysis of the Ural delta, taking into account its potential for tourism development. The delta of the described river is an important natural value due to its tourist values. It can be classified in the geosites category as a valuable asset affecting the tourist potential of the region. This scientific article discusses the methodology of landscape-ecological analysis of the delta areas in consideration of anthropogenic transformation of natural environmental components. We identified the main factors of anthropogenic transformation of the soil and vegetative cover. By employing geographic information technologies (software support and satellite data), up-to-date soil and vegetation maps of the Ural delta were created. With the help of estimated geoecological figures, we produced a map displaying anthropogenic disturbance of landscapes. The obtained results can be applied in territorial planning and ecological-geographical studies for construction of large economic objects.
\end{abstract}

Keywords: river delta, landscape, landscape analysis, man-induced impact

\footnotetext{
* Corresponding author
} 


\section{INTRODUCTION}

Currently, landscape-ecological analysis is considered one of the most important methods in the study of the natural capacity of a territory, which takes into account structural and functional dynamic features of natural complexes of different taxonomic ranks. The method ultimately aims to study the current ecological situation of any region, which determines the contemporary state of landscape complexes and depends on the proportionality of the projected social functions and natural properties of landscape complexes and their stability (Kochurov, 2003). Varied tourist values of places increase the possibility of practicing various forms of tourism (Gozner \& Avram, 2010; Ilieş \& Wendt, 2015; Ilieş et al., 2009; Tatar et al., 2017). The work presents a landscape and ecological analysis of the Ural delta, taking into account its potential for tourism development. The delta of the described river is an important natural value due to its tourist values. It can be classified in the geosites category as a valuable asset affecting the tourist potential of the region (Gozner, 2010; Ilieş \& Josan, 2009; Wendt, 2011; Berdenov et al., 2016). Landscapeecological analysis of a territory focuses on the study of links between components of the natural environment, population, and economy through explicit assessment (i.e. through application of a set of analytical and synthetic quantified indicators that directly or indirectly characterize the degree of landscape sustainability (Mikhno et al., 2014).

\section{THE RESEARCH TERRITORY}

In 1935, the Ural delta included 7-10 main river branches including Bolshoy Yaitskiy, Maliy Yaitskiy, Zolotoy, Zarosliy, Bukharka, and Peretaska.

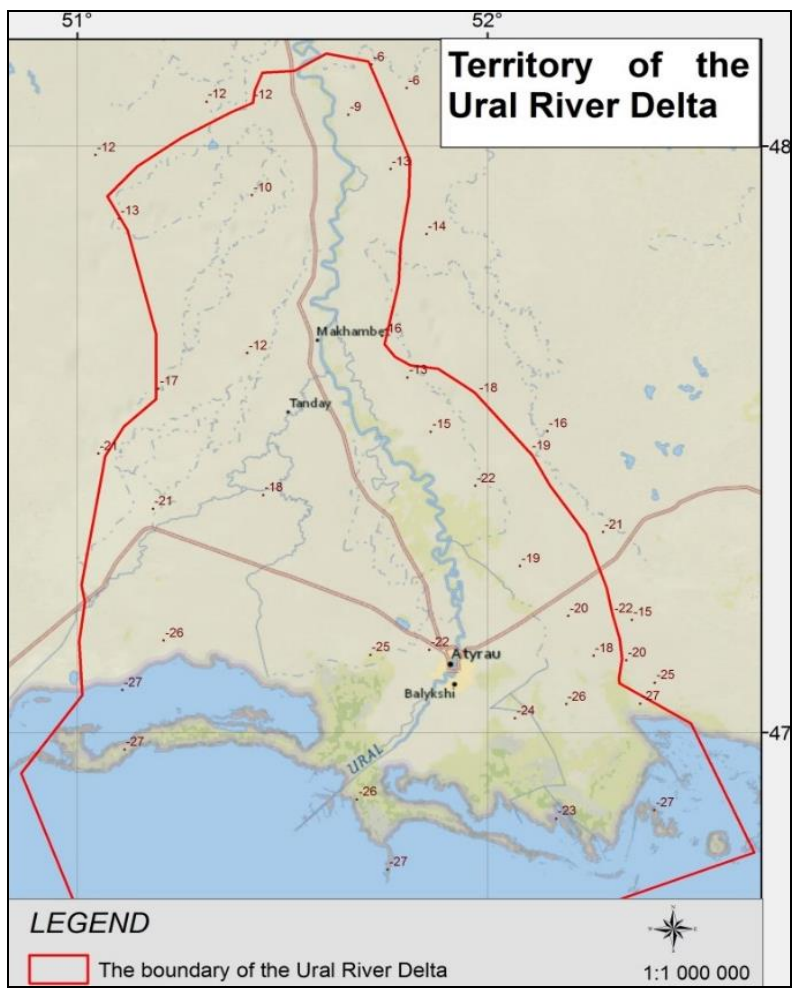

Figure 1. Map of the Ural (Zhayik) River Delta Territory 
At that time Zolotoy was the main branch, and the city of Atyrau was located $18 \mathrm{~km}$ away from the sea. Due to the lowering of water level by 1977, the left branches of Peretska, Bukharka, Zarosliy and Soltyenok silted up and now form inland dry depressions (Polonskiy \& Baydin, 1982). Nowadays, the Ural delta begins in the village of Zelyoniy which stands more than $170 \mathrm{~km}$ away from the current river mouth. The width of the river gradually increases from $10-15 \mathrm{~km}$ near Zelyoniy up to $60 \mathrm{~km}$ at the mouth. As far as the city of Atyrau, the Ural delta constitutes an ordinary river valley. At this point, two outflows, the Marynka and the Baksay, that only get filled with the water from the Ural in wet years, separate from the river. The Zolotoy branch forms a river part of the Ural-Caspian channel which, within a further $16 \mathrm{~km}$ of the estuarial coast, goes into a sea section of the channel to a depth of 1.8 meters. This channel connects the Ural mouth with the Ural Borozdina, the deepest area of the eastern part of the Northern Caspian. The Ural Borozdina is an extension of the underwater river bed of the Ural which was made by the river when the sea level was lower. In addition to the downstream, there is a meander floodplain along the river that has a width of 0.5 to $3 \mathrm{~km}$; its height above the water level of the river is gradually decreasing and currently ranges from 6 to 7 meters near the village of Topoli and remains up to 2 meters near the village of Kandaurovka, situated respectively $156 \mathrm{~km}$ and $24 \mathrm{~km}$ from the city of Atyrau (Figure 1).

The research territory is predominantly located in the southern part of the Caspian basin and includes the present-day Ural River delta and the adjoining shallow part of the sea which lies $27 \mathrm{~m}$ below sea level (present background sea level) down to $-23 \mathrm{~m}$ on land and down to $-29 \mathrm{~m}$ at sea as seen in Figure 1. The north-west to south-east length of the research area is $85.2 \mathrm{~km}$ with an average width of $43 \mathrm{~km}$ and a total area of $2,751.6 \mathrm{~km}^{2}$.

\section{MATERIALS AND METHODS}

Traditional approaches of geographical research were used for collection and analysis of materials. The solution of the main goal of this work - to define the anthropogenic variability of the Delta part of the Ural basin - was based on the implementation of comparative-geographical and landscape-cartographic analyses, scientific expeditions, and other research methods to study the dynamic natural sites.

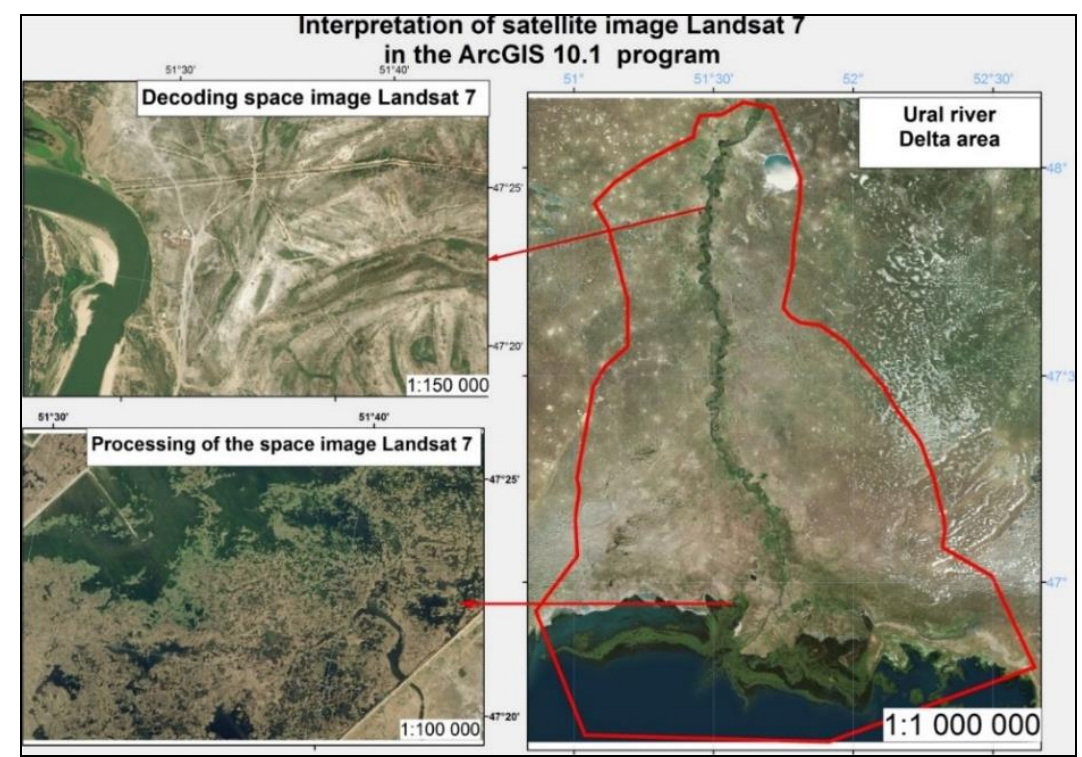

Figure 2. Satellite image interpretation (Landsat7) 
Landscape analysis of the territory is a system matrix of geo-ecological assessment of territories. The notion of landscapes makes the most common expression of a systemic approach to nature (Mikhno et al., 2014). A landscape is a hierarchy of natural formations of different temporal and spatial scales, a set of interrelated natural components (lithogenic basis, air masses, natural waters, soils, vegetation, and wildlife) in the form of territorial entities of various hierarchical ranks (Berdenov, 2015).

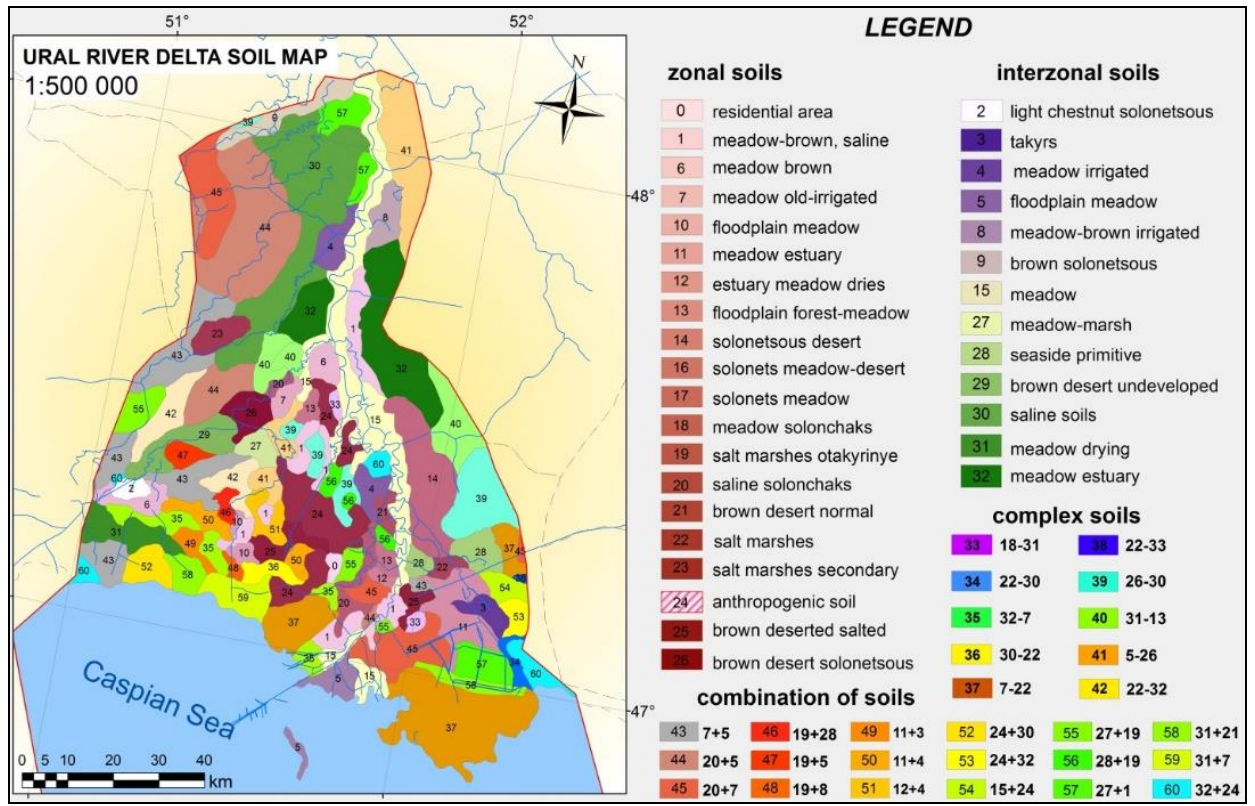

Figure 3. Soil map of the research territory

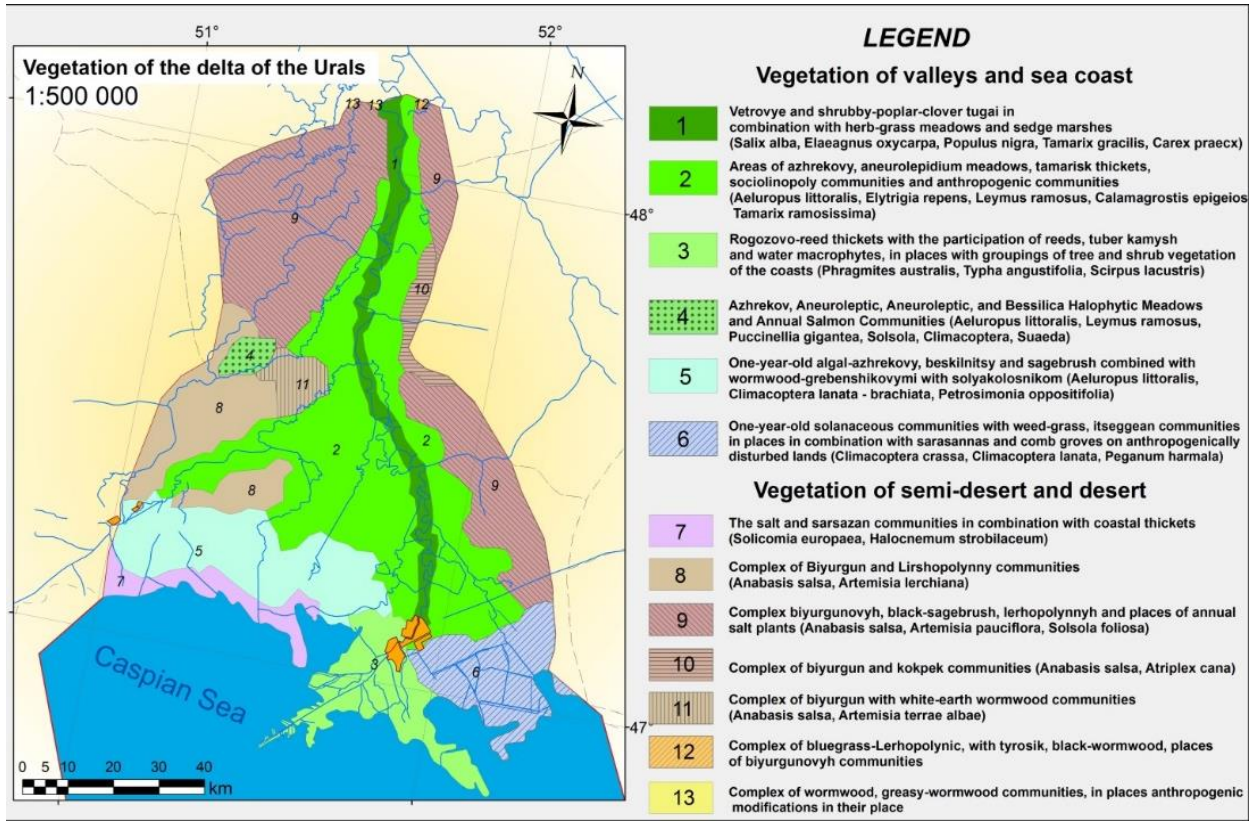

Figure 4. Vegetation map of the Ural River delta 
The components of the landscape contain a material-energy and information exchange which is the biogeochemical circulation of elements that characterize a landscape as a whole geosystem. Information interrelations within landscapes can be traced in both space and time, and indicate that certain natural components transfer territorially and temporally ranked diversity to others (Chibilev, 1987).

The studies were conducted in the summers of 2016-2017. Digital topographic maps of 1:100,000 scale, satellite images of Landsat 7 with a resolution of 15-30 m., and published archive data served as the primary source data of the research (Meldebekov \& Bayzhanov, 2005). Digital images were employed to update information on the coastline, road network, settlements, agricultural areas, etc. The images were interpreted through taught classification, and the interpretations were supplemented and duly adjusted by expertise (Figure 2). In decoding, we received up-to-date maps of the vegetation and soil cover (Figures 3 and 4). A landscape map of the Ural river delta at a scale of 1:500,000 was prepared based on the principles of hierarchical structure of geosystems through integration of structural and structural-dynamic parameters and by taking into account the economic activity of the areas and by drawing on landscape profiling and standardization of index plots (Figure 5).

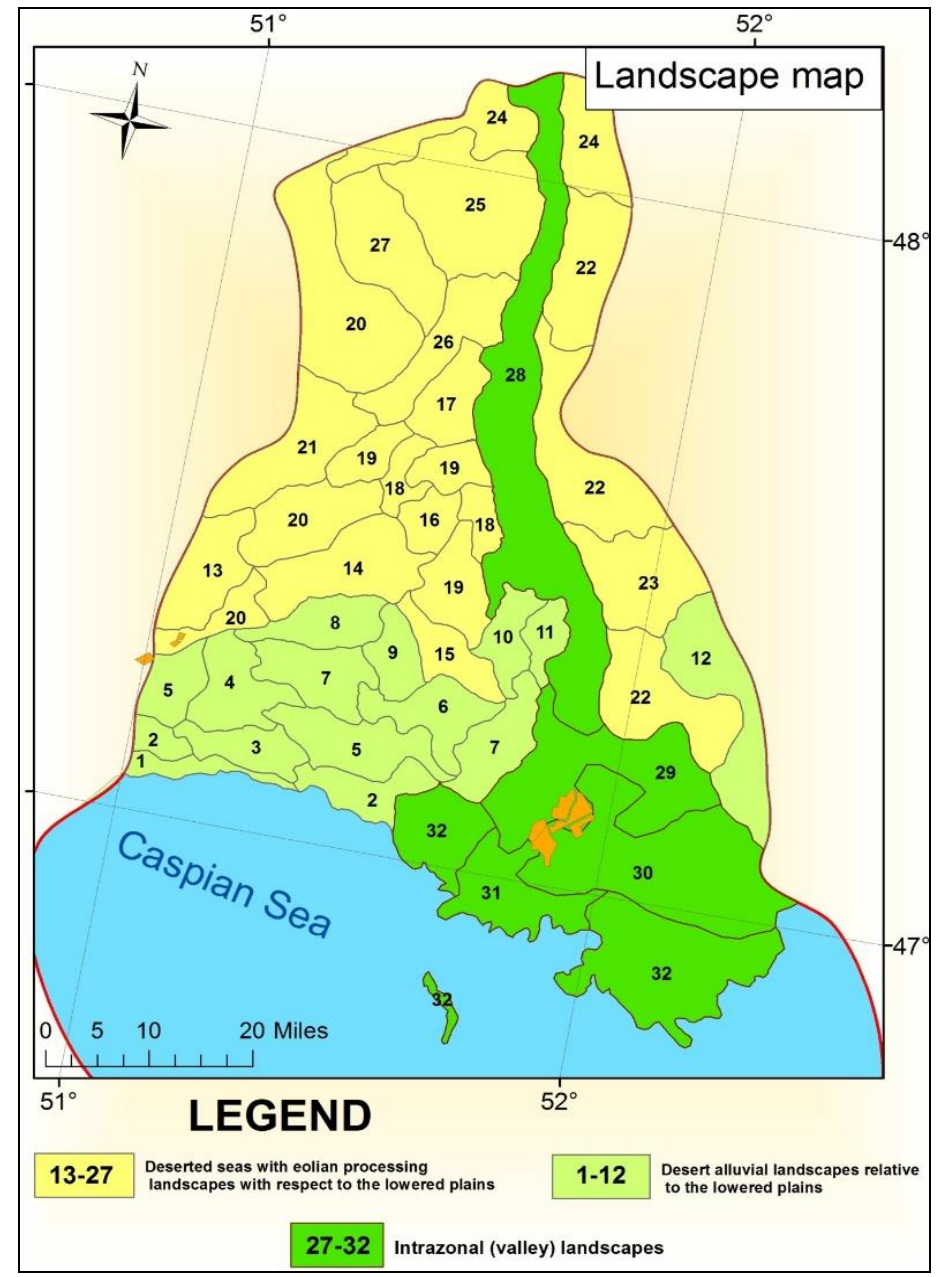

Figure 5. Landscape map of the Ural River delta 
Landscape ecological analysis takes into account landscape differentiation of the territory with allocation of ecological-landscape zones and expresses sustainability of the territory to external impacts delivered in certain parts of the landscape (areas, stows, substows, and facies). The result is a territorial frame of nature management with ecologically homogeneous areas (Amirzhanovna et al., 2017).

It seems necessary to use a differentiated approach to assess the landscape ecological state of the delta territories. This, in turn, entails the presence of structuring criteria of the ecological state of landscape complexes of the corresponding taxonomic rank. Specification of a representative set of analytical and synthetic quantitative indicators should be based on structural specifics of morphological complexes (first on terrain types and their variants, and groups of stow kinds) that set the landscape capacity of the relative region.

Landscape-ecological analysis of the research area is based on methodological works in two directions (Methodology Instructions, 2005): impact area and impact level. The final step is an overall assessment of natural territorial complexes by way of summing up the obtained data and mapping the anthropogenic impact on the landscape of the Ural River delta (Yeginbayeva et al., 2016).

To that end, the following factors of landscape ecological assessment were defined: structural-morphological aspects; adverse ecological and geographical processes; anthropogenic transformation of landscapes; ecological infrastructures of landscapes; and environment-oriented factors (Mikhno et al., 2014).

Structural-morphological assessment of landscapes. Structural-morphological assessment of landscape complexes is a primary and necessary component of landscape ecological studies of any territorial unit, both natural (natural area, province, stow, facie) and social (region, district).

Assessment of anthropogenic transformation of landscapes. This is another mandatory element of landscape ecological analysis of the municipal districts territory. Exceeding a certain level of anthropogenic load leads to disruption of ecological links between natural components and landscape complexes, to decreased ability of selfregeneration, and ultimately to degradation of geosystems.

Assessment of negative ecological and geographical processes. Two groups of natural-anthropogenic processes have particular importance in assessing the ecological state of the residential districts of the Zhayik River delta: contamination of certain landscape components, and development of exodynamic processes.

In order to determine the ecological state of the landscape we conducted quantitative (4-point) rating of factors according to A. G. Isachenko (Isachenko, 1993) to identify the degree of impact on natural territorial complexes and single components of nature; their maximum and minimum values can be interpreted as a criterion of an important ecological factor. Based on this, we distinguish the following categories of anthropogenic load on the landscapes:

- landscapes of minor anthropogenic impact are those where only single components of the natural complex are affected and the disturbance is reversible;

- landscapes of low anthropogenic impact are those where the load is subject to the single landscape components, mainly vegetation, but the ability of regeneration is present and close to the original;

- landscapes of middle anthropogenic impact are those where a large part of the components of the natural complex is subject to load so that the natural complex is substituted by a natural-anthropogenic one;

- landscapes of strong anthropogenic impact are those where the load is applied to all components, i.e. the natural complex is changed by a natural-anthropogenic one. 


\section{RESULTS AND DISCUSSION}

In order to define climatic conditions of the Atyrau index plot, we used the mean annual data on "RSE KazGydromet" meteorological stations over the past five years. The study area is located in the southern part of the Caspian basin to the below-sea absolute level of $-27 \mathrm{~m}$. The geological cross-section of the research area distinguishes basement and platform sedimentary cover.

Crystalline basement rocks within the site are found at depths of $7-8 \mathrm{~km}$. The structure of sedimentary cover distinguishes subsalt, salt, and above-salt complexes. The above - salt complex includes rocks from the upper Permian to the Quaternary inclusive, which are mostly clay and sandy layers with bands of limestone and marlstone.

The terrain of modern alluvial-deltaic plains situated on both banks of the Ural River downstream of Atyrau looks relatively more dissected. The plains surface is complicated by deltaic channels, meander lakes and numerous draws. The width of the plain in the north of the site is $17 \mathrm{~km}$; it gets narrower south-westwards and is $14 \mathrm{~km}$ wide here. The delta plains are composed of loams, sandy loams and sands with a capacity of up to $3 \mathrm{~m}$, which are underlaid by sea late-Khvalynskiy clay deposits. The studied area belongs to the Aral-Caspian province of the desert zone, where zonal soil types are brown desert soils (Faizov, 1983). Morphogenetic properties of the soil and structure of the soil cover of the researched territory is explained not only by zonal but also largely by hydrological factors. Processes of soil formation in the deltaic area are closely linked to the fluctuations at modern sea level (Figure 2). Changes in hydrological conditions associated with fluctuating levels of the Caspian Sea have become so dynamic that the signs of soil-forming process cannot gain a foothold in the end-products of soil formation. The fluctuation of the sea level floods the already formed soils under marine sediments. Today the flooded narrow coastal strip undergoes enhanced hydromorphism and desalinization of soils. We made 25 soil profiles as part of the field research (Figure 6).

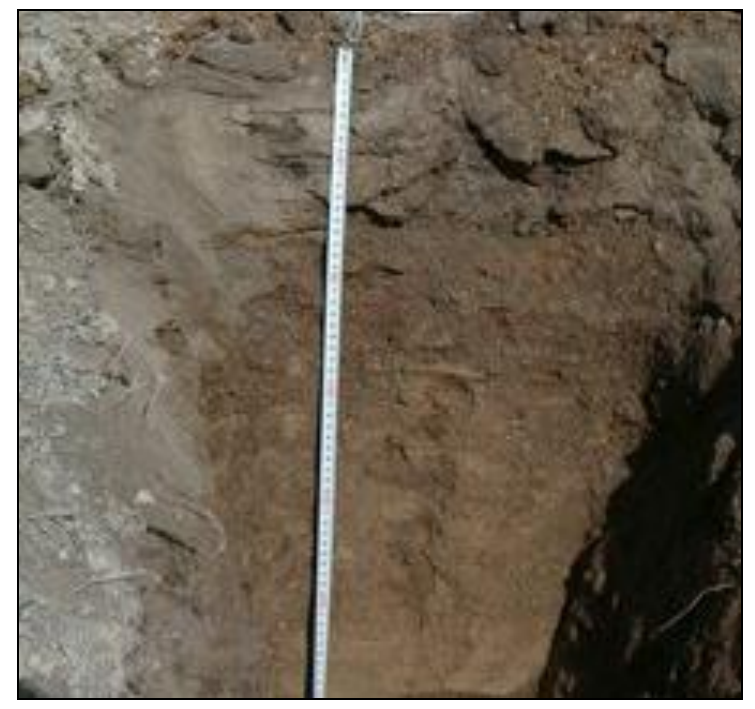

Figure 6. Soil profile No. 3 (Seaside Solonchak Profile)

We selected soil samples from 15 profiles for chemical analyses (humus, exchangeable bases, exchange capacity, mechanical structure, etc.). The total number of samples for general analyses exceeded 100.

The results of chemical analyses are shown in Table 1. 
Landscape Ecological Analysis of the Modern Delta of the Ural (Zhayik) River

Table 1. Basic chemical properties of the soil

\begin{tabular}{|c|c|c|c|c|c|c|c|c|c|c|c|}
\hline \multirow{3}{*}{$\begin{array}{l}\text { Profile } \\
\text { No. }\end{array}$} & \multirow{3}{*}{$\begin{array}{l}\text { Depth, } \\
\text { cm }\end{array}$} & \multirow{3}{*}{$\underset{\%}{\text { Humus, }}$} & \multirow{3}{*}{\begin{tabular}{|c|} 
Total \\
Nitrogen, \\
$\%$
\end{tabular}} & \multirow{3}{*}{$\mathrm{CO}_{2}, \%$} & \multirow{3}{*}{ Gypsum } & \multirow{2}{*}{\multicolumn{5}{|c|}{$\frac{\text { Absorbed Bases, mg-equ }}{\text { for } 100 \mathrm{~g} \text { of soil }}$}} & \multirow{3}{*}{$\mathrm{pH}$ water } \\
\hline & & & & & & & & & & & \\
\hline & & & & & & $\mathrm{Ca}$ & $\mathrm{Mg}$ & $\mathrm{K}$ & $\mathrm{Na}$ & Total & \\
\hline \multirow{4}{*}{1} & 0-18 & 2.8 & \begin{tabular}{|l|}
0.15 \\
\end{tabular} & 4.46 & - & & & & & & 8.3 \\
\hline & 18-33 & 1.5 & & 3.73 & - & 14.5 & 36 & 0.61 & 3.87 & 54.98 & 8.2 \\
\hline & $44-54$ & & & 2.38 & 2.09 & 4 & 12.5 & 0.36 & 0.46 & 17.32 & 8.98 \\
\hline & $72-82$ & - & & 2.42 & 1.67 & & & & & & 8.95 \\
\hline \multirow{4}{*}{2} & $0-13$ & & 0.1 & & & & & & & & 8.15 \\
\hline & $23-33$ & & & & & & & & & & 8.05 \\
\hline & $44-54$ & & & & & & & & & & 8.2 \\
\hline & $72-82$ & & & & & & & & & & 8.32 \\
\hline \multirow{4}{*}{5} & $0-16$ & $1 ., 3$ & 0.05 & 15.43 & - & 3.5 & 3.5 & 0.21 & 1.22 & 8.43 & 9.1 \\
\hline & $18-28$ & 0.35 & & 9.85 & & 6 & 4 & 0.26 & 2.76 & 13.02 & 8.4 \\
\hline & $35-45$ & & & 6.35 & & 8 & 8 & 0.75 & 2.01 & 18.76 & 8.56 \\
\hline & $62-72$ & - & & 3.48 & 3.21 & & & & & & 8.7 \\
\hline \multirow{3}{*}{6} & $0-12$ & 0.06 & 0.03 & & & & & & & & 9.51 \\
\hline & $15-25$ & 0.26 & & & & & & & & & 8.9 \\
\hline & $44-54$ & & & & & & & & & & 8.96 \\
\hline \multirow{3}{*}{7} & $0-16$ & 1.28 & 0.07 & & & & & & & & 9.25 \\
\hline & $27-37$ & & & & & & & & & & 8.54 \\
\hline & $60-70$ & & & & 13.58 & & & & & & 8.64 \\
\hline \multirow{3}{*}{8} & $0-6$ & 1.48 & 0.08 & & & & & & & & 9 \\
\hline & 9-19 & 0.66 & & & & & & & & & 9.53 \\
\hline & $36-46$ & & & & & & & & & & 8.56 \\
\hline \multirow{5}{*}{9} & $0-18$ & 0.1 & 0.04 & 5.37 & & 7.5 & 5.5 & 0.42 & 1.77 & 15.19 & 8.3 \\
\hline & $21-31$ & 0.23 & & 5.44 & & 9.5 & 11 & 0.33 & 0.91 & 21.74 & 8.1 \\
\hline & $38-48$ & & & 3.32 & & 3 & 6.5 & 0.37 & 1.08 & 10.95 & 8.25 \\
\hline & $59-69$ & & & 3.73 & 0.23 & - & - & - & - & - & 8 \\
\hline & $98-108$ & & & 5.83 & 2 & - & - & - & - & - & 8.1 \\
\hline \multirow{4}{*}{10} & $0-19$ & 0.1 & 0.04 & & & & & & & & 9.05 \\
\hline & $29-39$ & & & & & & & & & & 8.97 \\
\hline & $70-80$ & & & & & & & & & & 8.89 \\
\hline & $110-120$ & & & & & & & & & & 8.91 \\
\hline \multirow{4}{*}{12} & o-18 & 0.26 & 0.04 & & & & & & & & 9.05 \\
\hline & $19-29$ & 0.13 & & & & 5.5 & 4.5 & 0.21 & 0.41 & 10.62 & 9.18 \\
\hline & $30-40$ & & & & & 10.5 & 7.5 & 0.23 & 0.65 & 18.88 & 8.85 \\
\hline & $60-70$ & & & & & & & & & & 8.37 \\
\hline \multirow{3}{*}{15} & $0-20$ & 0.1 & 0.04 & & & & & & & & 8.87 \\
\hline & $30-40$ & 0.03 & & & & & & & & & 8.58 \\
\hline & $65-75$ & & & & & & & & & & 8.35 \\
\hline
\end{tabular}

There were collected samples for abbreviated water analysis from 5 profiles where groundwater was present. We collected composite samples from 10 plots from surficial horizons for chemical analyses aiming to detect heavy metals. The results of the chemical analysis are shown in Table 2. Data on all profiles and analyses of soil cover was recorded in a geodatabase. As the results of the chemical analyses demonstrate, the content of active forms of copper, zinc, cadmium, lead, and cobalt are within the limits of maximum permissible concentrations (MPC) throughout the territory. As for active nickel, the highest nickel content can be seen in samples collected in the city of Atyrau (1.5 of MPC) and at the spots located $15 \mathrm{~km}$ to the south of Atyrau (1.7 to 1.9 of MPC). A similar 
situation is with active chrome, the highest concentrations (up to 1.9-2.2 of MPC) of which are recorded at the spot that is close to the airport and in the city of Atyrau (within 2-4 km), particularly in the area where soil is exposed to the highest anthropogenic loads.

Table 2. Content of heavy metals $(\mathrm{mg} / \mathrm{kg})$ in soil

\begin{tabular}{|c|c|c|c|c|c|c|c|c|}
\hline $\begin{array}{c}\text { Profile } \\
\text { No. }\end{array}$ & \begin{tabular}{|l|} 
Sampling \\
Depth, cm
\end{tabular} & Zinc & Copper & Lead & Cadmium & Cobalt & Nickel & Chrome \\
\hline \multicolumn{9}{|c|}{ Active Forms } \\
\hline 1 & $0-10$ & 0.9 & 0.9 & 8 & 0.5 & 2.4 & 3.2 & 6.9 \\
\hline 2 & $0-10$ & 0.8 & 0.2 & 4.5 & 0.2 & 1.3 & 2 & 4.2 \\
\hline 3 & $0-10$ & 0.9 & 0.7 & 6.4 & 0.5 & 1.6 & 5.1 & 10.4 \\
\hline 4 & $0-10$ & 1.3 & 1 & 5.7 & 0.4 & 1.9 & 4.1 & 8.6 \\
\hline 5 & $0-10$ & 0.9 & 0.8 & 8.6 & 0.6 & 2.2 & 4.8 & 9.2 \\
\hline \multicolumn{2}{|c|}{ MPC } & 23 & 3 & no & no & 5 & 4 & 6 \\
\hline \multicolumn{9}{|c|}{ Total Forms } \\
\hline 1 & $0-10$ & 21.2 & 8 & 12 & 0.9 & 7.2 & 25.2 & 68 \\
\hline 2 & $0-10$ & 20.4 & 6.4 & 8.8 & 0.9 & 6.8 & 27.6 & 80.4 \\
\hline 3 & $0-10$ & 74.8 & 21.6 & 14.2 & 0.9 & 14.8 & 67.6 & 176 \\
\hline 4 & $0-10$ & 28.4 & 12.4 & 10.2 & 0.8 & 9.2 & 34 & 104.8 \\
\hline 5 & $0-10$ & 44.4 & 12.8 & 17.2 & 0.9 & 11.2 & 35.2 & 120.4 \\
\hline \multicolumn{2}{|c|}{ MPC } & 110 & 23 & 32 & & & 35 & \\
\hline
\end{tabular}

The highest concentrations of total forms of heavy metals also belong to nickel. As for the mobile forms, nickel's content amounts to over 3 MPC in the area near Atyrau. A slight excess of total copper over MPC was detected. The study revealed that the highest crests of the head of the delta are composed of stratified layers of micaceous sands with interlayers of bluish-brown clays and clay loams covered with wormwood, estragon, woodreed and agropyron cristatum. There are many bushes of tamarisk and small willow groves. Disturbance of the researched area's soil cover is a consequence of anthropogenic factors. It comes in the form of areal degradation of soil and vegetation under the influence of a local factor, which is the elaboration of oil fields, quarries, construction of settlements, industrial objects and cattle-breeding farms, and of a linear factor which includes influence of the road network, communication lines, oil pipelines, canals, dams, etc. Frequently, the anthropogenic impact stimulates the natural processes of soil degradation (Mendybayev et al., 2015). Formation and dynamics of vegetation of the research area are subject to factors of direct influence of the sea, the Ural River floods and extreme flower variegation of soils. Therefore, the structure of vegetation and species diversity of natural communities are characterized by instability and weak soil maturity, due to the relative youth of the land and periodic changes of moisture and salinity of soils, especially in hydromorphic soils of washing mode.

The vegetation of the region was studied during the vegetation period of 2017 . Communities are represented mainly by meadow vegetation. In the wind-affected zone of marsh solonchaks, there is continuous cover of glasswort with some tamarisk. In the areas of close groundwater, there are shoreweed and alkali grass halophytic meadows with some shrubs and sub-shrubs. With more distance from the sea and lowering of groundwater levels, these plant communities are replaced by wormwood-grass and wormwood-tamarisk-grass, then shrub-saltwart, and - in the Eastern part of the research area - mortuk communities (Figure 3). A significant impact on plant cover transformation is produced by the use of land for grazing. Overgrazing gives rise to pasture degradation, a decrease in projective cover and change of grass stand, which, in 
turn, results in the replacement of feeding crops (wormwood grass) by weeds and plants with low feeding value (burweed, peganum, some saltwarts) (Bizhanova \& Kurochkina, 1989). Due to adverse climatic conditions, the vegetation of the research area transforms because of weak sustainability to anthropogenic impacts and extremely low compensatory capacity of regeneration and formation of secondary ecosystems, especially in technogenic ecotopes. The studies have shown that areas of severe disturbance are localized (around oil wells and construction objects), i.e. the effect does not cover large areas, hence we should expect more rapid growth of vegetation due to vegetative mobility of the main dominant species of wormwood and perennial saltwort. All the basic dominants such as wormwood and perennial glasswort (barnyard grass, sarsazan, anabasis) are characterized by stable regeneration and can quickly master the disturbed areas. However, newly formed secondary communities will lack a fully floristic composition and thus have an unstable structure (Zhamangara \& Lucas, 1999), which is why they will be vulnerable to all kinds of anthropogenic impacts for a long time.

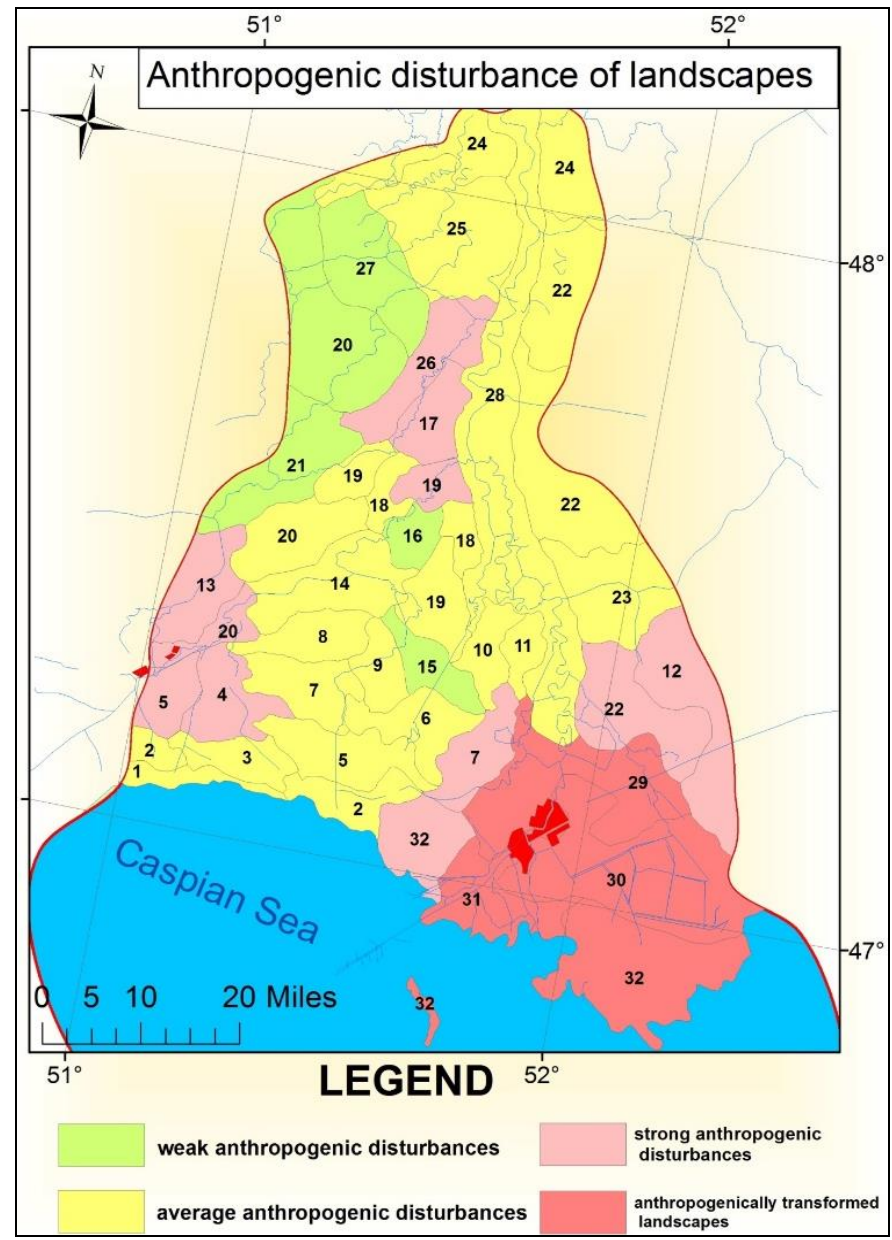

Figure 7. Map of anthropogenic disturbance of landscapes

The most stable and fast recovering communities are the ones of intrazonal meadow-shrub type (Nurmambetov \& Akiyanova, 1989) which are formed under 
conditions of excessive moisture and have a high biological variety of vegetation and multiple-tiered structure. The main dominant species (reed, shoreweed, saltmarsh grass, clubroot) reproduce easily by seed and vegetative propagation (Figure 7 - Landscape 1, 2, 3). The xerophytic suffruticósa desert vegetation emerging at zonal brown soils is relatively stable (Figure 7 - Landscape 7,22 ). The halophytic vegetation of salt marshes is poorly resistant. The communities are usually monodominant and have very few related species, and the conditions of the ecotopes (high salinity) limit the settling of other species. The natural vegetation near residential areas, oil fields and other economic objects is highly transformed, therefore the possibility of compensation is very low. Here, the formation of a secondary weed community similar to the surrounding area can be expected (Figure 7 - Landscape 29, 30, 31, 32). Full restoration of communities with no special phytomelirative measures is impossible as the areas have already lost their ecological and resource capacity. Landscapes of the deltaic zone of the Ural River are mostly characterized by local types of pollution. In light of this, we should consider, above all, local features of the territory when struggling against it. A suitable level of contamination investigation is meso-territorial, corresponding to the level of landscapes.

Geoecological assessment of the territory from an economic perspective is an essential component of landscape ecological studies. When studying the impact of human activities on the environment, performance indicators should reflect nature and intensity of anthropogenic load on the landscape. The main anthropogenic source of the research area is mining and processing of hydrocarbon deposits. Thus, following the results of various archive materials and chemical analyses of soil and vegetation samples obtained by the field methods, the anthropogenically most disturbed landscapes of the Ural River delta were defined according to a 4-point scale (Figure 7).

\section{CONCLUSIONS}

It has been established that landscape Figure 7 - Nos. 29, 30, 31 and 32 exist under the most difficult geo-ecological conditions, where all components of natural environment are transformed and a completely modified natural-technogenic complex is formed as they bear the main sources of technogenesis (factories, plants, etc.). This territory represents $20 \%$ of the total research area. Figure 7 - Landscape No. 30 is subject to strong anthropogenic load because it is situated in close proximity to anthropogenic sources.

Figure 7 - Landscape nos. 4, 5, 7, 12, 13, 17, 19, 20, 22, 26, and 32 exist in conditions of strong anthropogenic disturbance of natural components and are mainly concentrated in urban areas. Landscapes with a medium degree of disturbance of natural systems occupy the largest part of the research territory and equal $50 \%$ of the area. They are concentrated in the area of degradation of agricultural land. The landscapes least exposed to anthropogenic transformation are those under Figure $7-$ nos. 20, 21, 27 that are located in the eastern part of the Ural River delta as they are only partly used for grazing.

Following the results of the landscape ecological analysis in the context of migration and accumulation of elements in deposit environments, we conclude that the territory of the delta is primarily prone to the anthropogenic impact of the oil and petrochemical industry. The mining areas are characterized by complex ecogeochemical variety that includes supertoxic and toxic elements of the $1^{\text {st }}$ and $2^{\text {nd }}$ hazard classes.

\section{REFERENCES}

Amirzhanovna, Z.A., Zhanaleyeva, K.M., Galimzhanovich B.Z., Saparov, K.T., Mendybayev E.H., \& Atasoy, E. (2017). Assessment of hydrogeoecological features of the Yesil River Basin. In: Journal of Environmental Biology, Vol. 38, Issue 5, pp. 1115-1120. 
Berdenov, Z.G., Atasoy, E., Mendybayev, E.H., Ataeva, G., \& Wendt, J.A. (2016). Geosystems geological assessment of the basin of rivers for tourists valorization. Case study of Ilek river basin. In: GeoJournal of Tourism and Geosites, Year IX, no. 2, vol. 18, pp. 187-195.

Berdenov, Z.G. (2015). Technogenic impact on the landscape geosystems for example Kargaly district of Aktobe region. In: European Conference on Innovations in Technical and Natural Sciences, Austria, Vienna, pp. 74-79.

Bizhanova, G., \& Kurochkina, L.Y. (1989). Anthropogenic Pasture Changing of Moyinkums and Their Mapping. "Nauka" KazSSR, Alma-Ata, pp. 46-53.

Chibilev, A.A. (1987). To Landscape-Ecological Justification of Development of Protected Natural Area Network. In: A. A. Chibilev (ed.), General and Regional Issues of Landscape Geography of the USSR, Publishing House of Voronezh University, Voronezh, pp. 84-92.

Faizov, K.Sh. (1983). Soils of Desert Zone of Kazakhstan. "Nauka" KazSSR, Alma-Ata, pp. 230-239.

Gozner, M., Avram, M. (2010), The situation of the natural reservation from the Territorial System Albac - Arieseni, Analele Universităţii din Oradea, Seria Geografie, Tom XX, Editura Universităţii din Oradea; http://journals.indexcopernicus.com/karta.php?action=masterlist\&id=3951.

Gozner, M. (2010) Tourism in the Territorial System Albac - Arieseni sistemul teritorial Albac and its impact on the environment, Analele Universităţii din Oradea, Fascicula Construcţii şi Instalaţii Hidroedilitare, vol. XIII - 2, Editura Universităţii din Oradea

Ilieş, A., Wendt, J.A. (2015). Tourism geography. The basic of theory and application issues. [Geografia turystyczna. Podstawy teorii i zagadnienia aplikacyjne]. Wydawnictwo AWFiS, Gdańsk.

Ilieş, D.C., \& Josan, N. (2009). Geosites-geomorphosites and relief. In: GeoJournal of Tourism and Geosites, Year II, 1, pp. 78-85.

Ilies D. C., Blaga L., Hodor N., Josan I., Gozner M. (2009) „Estimation Of The Geomorphostructures With Geomorphosite Valence In The Northern Part Of The Hunedoara County (Western Romania)” în Analele Universităţii din Oradea, Seria Geografie, Editura Universităţii din Oradea; http://journals.indexcopernicus.com/karta.php?action=masterlist\&id=3951

Isachenko, A.G. (1993). Landscape and geographic prerequisites, St. Petersburg, Vol. 125, Issue 1.

Kochurov, B.I. (2003). Ecological Diagnostics and Balanced Development: Reference Book, Madzhenta Publ., Moscow.

Meldebekov, A.M., \& Bayzhanov, M.Kh. (2005). Closing Report to the Research Work on Assessment of Ecological State of Fauna and Ecosystems of Three Project Territories of the Ural River Delta with Adjoining Caspian Seashore and Tengiz-Kurgaldzhinskaya and Alakol-Sasyloskaya Systems of Lakes. Project of GEF/UNDP: KAZ/oo/G37. - Almaty, pp. 7-9.

Mendybayev, E.H., Atayeva, G., Berdenov, ZH., Atasoy. E. (2015). Geochemical Researches of Region Soil with Technogenic Influence in Terms of Borlinskiy Region. West Kazakhstan. In: Oxid Commun., Vol. 38 (4), pp. 1933-1941.

Mikhno, V.B., Bevz, V.N., Gorbunov, A.S., \& Bykovskaya, O.P. (2014). Landscape-Ecological analysis of Municipal Districts Territory. In: VSU Reporter, series: Geography. Geoecologiya, No. 3, pp. 40$48 \& 245-260$.

Nurmambetov, E.I., \& Akiyanova. F.Zh. (1998). Modern Terrain Forming on the Seashore and Sea Shelve of the Caspian Sea.

Polonskiy, V.F., \& Baydin, S.S. (1982). Flow Distribution and Redistribution in the Volga River Delta. In: SOGI, No. 161, pp. 111-122.

Tatar, C.F., Herman, G.V., Dehoorne, \& O., Zarrilli, L. (2017). Ecotoursim in the Danube Delta. In: Analele Universităţii din Oradea, Year XXVII, no. 1, pp. 122-132.

Wendt, J.A. (2011), Outline of tourism geography. [Zarys geografii turystycznej]. Wydawnictwo Uniwersytetu Gdańskiego, Gdańsk.

Yeginbayeva, A., Saparov, K., Aralbekova, M., Atasoy, E., Kizilçaoğlu, A., \& Wendt, J.A. (2016). The role of GIS mapping method in toponomy research. In: U.Ü. Fen-Edenbiyat Falultesi Sosyal Bilimler Dergisi, 19, Sayl 30, pp. 11-18.

Zhamangara, A.K., \& Lucas, S.G. (1999). Revision of some Eocene charophytes from the Zaysan basin, Eastern Kazakstan. In: Australian Journal of Botany, Vol. 47, Issue 3, pp. 297-304.

*** Geographical Principles of Sustainable Development of the Republic of Kazakhstan. Almaty, pp. 322-338.

** (2005) Methodology Instructions on Determining of Degrading and Polluted Lands Approved by Roskomzem. Ministry of Natural Resources of the Russian Federation, Moscow, pp. 240-245.

http://gis-lab.info/qa/landsat-glovis.html - (Landsat 7 https://earthexplorer.usgs.gov)

Submitted:

26.06.2018
Revised:

24.09.2018
Accepted and published online 26.09.2018 